\title{
Comparative Studies of Tracheary Element Structure of Some Gymnosperms with Angiosperms
}

\author{
Yuyuan Huang ${ }^{1,2^{*}}$, Yanhua Han ${ }^{1}$, Lijun Wei ${ }^{2}$, Jiazhuo Wang ${ }^{3}$ \\ ${ }^{1}$ College of Life Sciences, Zhongkai University of Agriculture and Engineering, Guangzhou, China \\ ${ }^{2}$ Agricultural College, Guangxi University, Nanning, China \\ ${ }^{3}$ Guangxi Subtropical Institute of Crops, Nanning, China \\ Email: *huangyy233@126.com
}

How to cite this paper: Huang, Y.Y., Han, Y.H., Wei, L.J. and Wang, J.Z. (2017) Comparative Studies of Tracheary Element Structure of Some Gymnosperms with Angiosperms. American Journal of Plant Sciences, 8, 959-984.

https://doi.org/10.4236/ajps.2017.85064

Received: October 27, 2016

Accepted: April 14, 2017

Published: April 17, 2017

Copyright $\odot 2017$ by authors and Scientific Research Publishing Inc. This work is licensed under the Creative Commons Attribution International License (CC BY 4.0).

http://creativecommons.org/licenses/by/4.0/

\begin{abstract}
Tissues of the pinna and rachis of Cycas diannaensis and pinna, rachis, and root of Cycas taiwaniana, rachis of Cycas szechuanensis, stem of Metasequoia glyptostroboides (Taxodiaceae), stems of Chamaecyparis obtusa (Sieb.et Zucc.) Endl cv. Tetragona (Cupressaceae), and leaves and stems of Michelia alba and Michelia figo and stems of Amygdalus persica (angiosperms) were compared using the scanning electron microscopy. In all species of these gymnosperms, their many tracheary elemnts have perforations in end walls and lateral walls. These structures are the same as vessels of angiosperms; therefore, these tracheary elements are vessel elements. Many types of vessels were found in cycads: pitted vessels in M. glyptostroboides, spiral and pitted vessels in Chamaecyparis obtusa cv. Tetragona. The development and structural characteristics of vessels of cycads, the two other gymnosperms, and the angiosperms were identical. Some characters such as extent of incline of perforation plate in the end wall showed that vessel characters of some angiosperms were more primitive than the cycads or M. glyptostroboides and C. obtusa cv. Tetragona. Many of the vessel elements of the angiosperms were band shaped, without end walls, and had only two lateral walls and other two margins; the end was acuate or with an arc margin; the end of some vessel elements was acute with no perforations, many perforations located only in lateral wall. Such results are rarely reported in previous work. In all species, perforations were seen only in tracheae, and the walls of parenchyma cells only had a thin primary wall and without perforation. Analysis and discussion to the experimental measures which were observed and research of the structure of vessel or tracheid, pointed out that several measures all could be used and the Jeffrey' method effects were better. Comparing the vessels of cycads, Taxodiaceae and Cupressaceae helps us to understand the mechanism in which these most
\end{abstract}


primitive or more primitive extant gymnosperms were adapted to harsh environments and to understand these species' evolutionary extent, and has the significance to the studies of plant anatomy, plant systematics and plant evolution.

\section{Keywords}

Adaptability, Gymnosperm, Angiosperm, Evolution, Vessel, Structural Characteristics

\section{Introduction}

Cycads are very primitive seed plants of ancient origin from about the Carboniferous period [1], and still possess primitive characteristics in external morphology and internal structure, such as sperm with flagella. Metasequoia glyptostroboides $\mathrm{Hu}$ et Cheng is an ancient, rare "living fossil"; Chamaecyparis obtusa (Sieb.et Zucc.) Endl cv. Tetragona is also a more primitive genus of gymnosperm. Research on more species of gymnosperms regarding structural characteristics of tracheary elements is important to understand their adapted mechanism and evolutional extent. Such research can also promote effective measures to cultivate, breed and create the right conditions for increasing the individual number of population in the natural community. In 1999, Huang and Zhang published a brief report on the first discovery of vessels in Zamia furfuracea of cycads [2]. Lin \& Huang published another brief report on vessel features in the root of Cycas elonga [3], and another brief report on discovered vessel in the plant of Stangeriaceae [4]; Huang and Liao [5] published a brief report on discovered vessel in Coniferae and Taxinae, and Huang and $\mathrm{Wu}$ [6] discovered vessels in Cycas panzhihuaensis. Huang et al. [7] reported the structural feature of vessels on four genera of cycads and some angiosperms; Huang et al. [8] published the structural characteristics of vessels in three families of Cycadopsida.

The present report is a comparative study on structural features of the xylem of these gymnosperms and the angiosperms in attempt to further research more species of gymnosperms.

\section{Materials and Methods}

The pinna and rachis of Cycas diannaensis Z. T. Guan et G. D. Tao and the pinna, rachis, and root of $C$. taiwaniana Carruth (Cycadaceae) were collected from living cycads in the Cycad Garden of Shenzhen Fairy Lake Botanical Garden, Shenzhen, China. The rachis of Cycas szechuanensis, stem of Metasequoia glyptostroboides $\mathrm{Hu}$ et Cheng of Taxodiaceae and Chamaecyparis obtusa (Sieb.et Zucc.) Endl cv. Tetragona (Cupressaceae) were collected from the South China Botanical Garden, Guangzhou, China. Leaves and stems of Michelia alba DC. and $M$. figo (Lour) Spreng and stem of Amygdalus persica Linn were collected from the campus of Guangxi University, Nanning, China. Above all materials were random sampling, therefore, ensure whether these different plant taxon 
maybe almost all plants are having the characteristics under the condition of random sampling. After collection, these materials were cut into $1 \times 1 \mathrm{~cm}$ pieces and fixed immediately in FAA (formalin: acetic acid: glacial ethanol $70 \%$, 5:5:90), then macerated and dissociated by $10 \%$ nitric acid $+10 \%$ chromate solution,volume proportion 1:1 (strict control dissociated situation, only then tissue disentwine was stoped at once) [9] [10], and rinsed with water (Jeffrey's method). The rachis of Cycas szechuanensis were sectioned by hand, the method as the literature [11] [12]. The dissociated and section materials were dehydrated in a graded series that $100 \%$ ethanol and isoamy acetate were according with the proportion of 1.0:0 $\rightarrow$ 0.3:0.7 $\rightarrow$ 0.5:0.5 $\rightarrow$ 0.3:0.7 $\rightarrow$ 0:1.0 and, critical pointdried in $\mathrm{CO}_{2}$, then sputter-coated with gold for observation and photography using XL-30 ESEM and JEM-1200Ex/s scanning electron microscope (SEM).

\section{Results}

In the leaf, stem and root tissues of plants of Cycadaceae, Taxodiaceae, Cupressaceae, and two families of angiosperm, their tracheary elements have perforations in end wall and lateral wall; numerous types of vessel elements were found. The structural constitution of tracheary element in three families gymnosperms are same or basic same as two families of angiosperm, but every species has itself feature in detail morphology character. The structural characteristics of these vessels are described next.

\subsection{Cycas diannanensis}

There are scalariform vessels, reticular vessels, pitted vessels and scalariformpitted vessels in the pinna, rachis and stem; the mesh of some reticular elements was irregular (Figure 1(a)), while that of a portion of these elements, near scalariform vessels, is more regular (Figure 1(b)). In some scalariform vessels, the perforation plate of the end wall is more inclined, 6 - 7 scalariform perforations in the plate (Figure 1(c)), In some pitted vessel elements, about 12 - 14 perforations distributed in the incline multiple perforation plate of end wall (Figure $1(d)$ ). The vessel some data of dimensions of structure of all species see Table 1 .

In these vessel elements, perforations are found in the lateral wall (Figure 1(a), Figure 1(b), Figure 1(e), and Figure 1(f)). Many perforations are so large to 16 - $24.1 \mu \mathrm{m}$ long, 5.2 - $6.0 \mu \mathrm{m}$ wide, that the ornamentation and perforations on the interior wall of the vessels are clear (Figure 1(a), Figure 1(e)). In reticular vessels, some septa or bars of ornamentation consist of secondary wall shape a sloping arrangement (Figure 1(b), Figure 1(f)), these scalariform, reticular and pitted vessel elements are large, the diameter see Table 1 . Some have several ridges on the outside of the vessel element.

The parenchyma cells have only a primary wall, which is not dissolved by enzymes [13]; wherefore preserve their integrity of wall of thin membrane shape, and have no perforations (Figure 2(a), Figure 2(b)).

Many scalariform vessels possess near horizontal or horizontal end walls and 4 - 5 perforations in the perforation plate (Figure 2(a), Figure 2(c)). Two adja- 
cent end walls that connect each other are also near horizontal status (Figure $2(a)$ ). Some pitted vessels are smaller. The lateral walls of these pitted vessels have many perforations (Figure 2(b)). In some vessel elements, some sections of
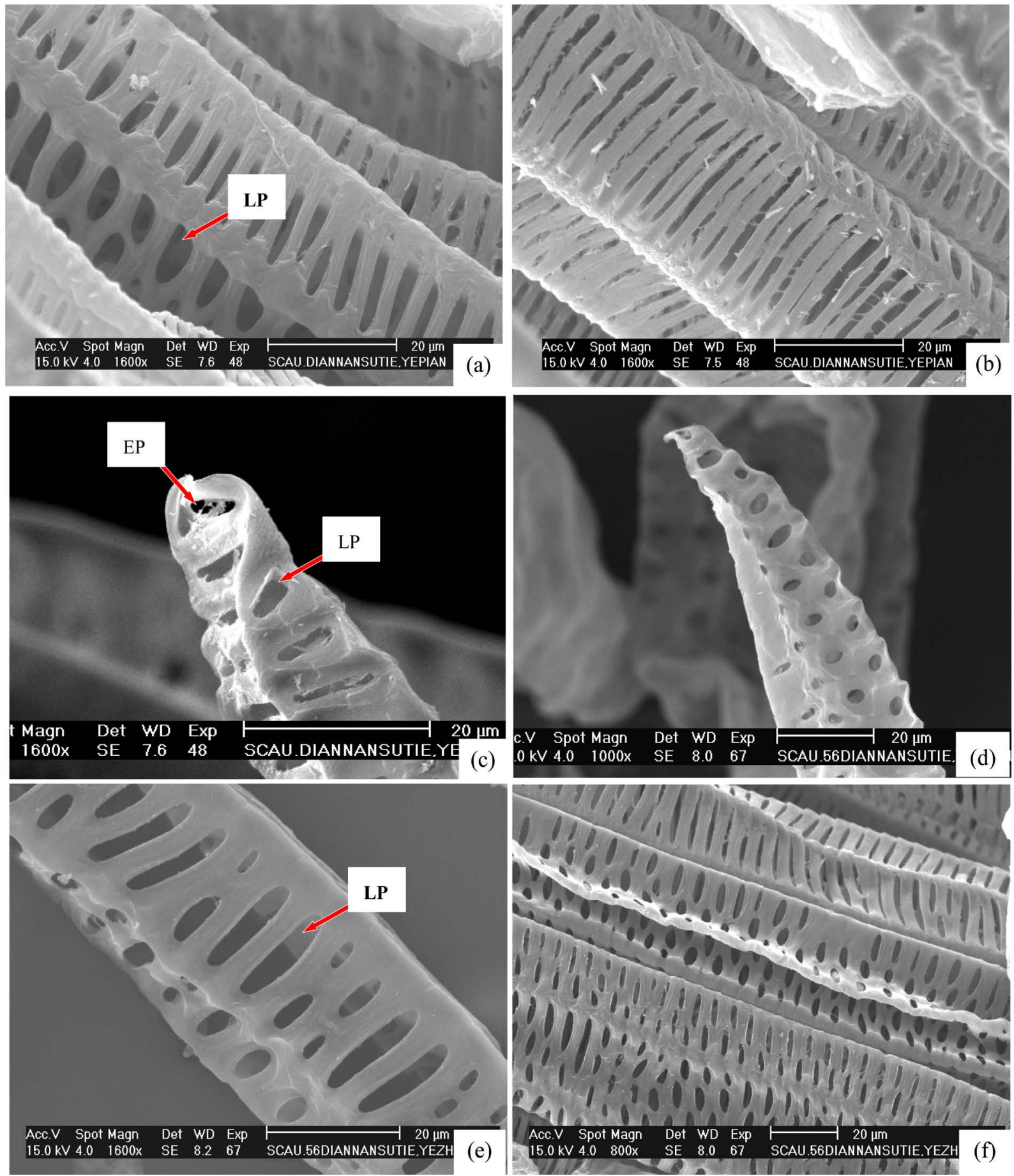

Figure 1. SEM photographs of vessel elements of pinna and rachis of Cycas diannanensis. (a) Several reticular vessel elements of pinna which have some irregular meshes, there more perforations locate in lateral wall (LP: lateral perforation). (b) Showing reticular vessel elements of pinna, some long perforations locate lateral wall. (c) A scalariform vessel element of pinna which possess several perforations in end wall (EP: end wall perforation plate). (d) A pitted vessel element of rachis, there is some perforations in end wall. (e) A reticular vessel element of rachis, some perforations is large, so that the ornamentations and perforations in the interior walls can be seen. (f) Several reticular vessel elements of rachis which possess irregular bars and perforations. 
Table 1. The data comparing of vessel characters of four families.

Unit: $\mu \mathrm{m}$

\begin{tabular}{|c|c|c|c|c|c|c|c|}
\hline \multirow{2}{*}{ Taxon } & \multicolumn{2}{|c|}{ Vessel } & \multicolumn{3}{|c|}{ Perforations of End wall } & \multicolumn{2}{|c|}{$\begin{array}{l}\text { Perforation of } \\
\text { Lateral wall }\end{array}$} \\
\hline & Type & Diameter & Number & Length & Width & Length & Width \\
\hline \multirow[t]{4}{*}{ Cycas diannanensis } & Scalariform & $17.6-19.6$ & $\begin{array}{l}4-5 \\
(6-7)\end{array}$ & $7.5-8.0$ & $2.2-3.1$ & & \\
\hline & Pitted & $14.6-15.8$ & $12-14$ & $5.6-6.3$ & $3.5-4.0$ & & \\
\hline & Reticular & $34.7-56.1$ & $17-20$ & $15-17$ & $3.4-5.2$ & $16-24.1$ & $5.2-6.0$ \\
\hline & $\begin{array}{l}\text { Scalariform, reticular } \\
\text { and pitted }\end{array}$ & $\begin{array}{c}22-30 \\
(40-46)\end{array}$ & & & & & \\
\hline \multirow[t]{4}{*}{ C. taiwanensis } & Annular and spiral & $10.03-12.69$ & 1 & 8 & 8 & & \\
\hline & $\begin{array}{c}\text { Scalariform, } \\
\text { scalariform-reticular }\end{array}$ & $18.6-25.2$ & & & & $9.8-10.2$ & $2.2-3.1$ \\
\hline & Reticular vessels & $21.4-25.3$ & $16-22$ & $9.8-13.6$ & $4.1-4.25$ & $9.8-10.4$ & $2.1-3.5$ \\
\hline & Scalariform-pitted & $20-23.7$ & & & & $8.2-9.4$ & $2.8-3.2$ \\
\hline \multirow[t]{3}{*}{ C. szechuanensis } & Annular, spiral & $20-25$ & & & & $20-35$ & $15-18$ \\
\hline & Scalariform vessels & $17-30$ & $3-4$ & $8-10$ & $5-7$ & $16-18$ & $6-10$ \\
\hline & $\begin{array}{c}\text { Reticular, } \\
\text { Pitted-reticular }\end{array}$ & $22-49$ & & & & $5-7$ & $4-6$ \\
\hline $\begin{array}{c}\text { Metasequoia } \\
\text { glyptostroboides }\end{array}$ & Pitted & $11.2-17.0$ & $2-4$ & $5-6$ & $5-6$ & 6.2 & 6.2 \\
\hline \multirow{2}{*}{$\begin{array}{c}\text { Chamaecyparis } \\
\text { obtusa cv. Tetragona }\end{array}$} & Spiral & $4.0-4.2$ & 1 & 2.8 & 2.2 & & \\
\hline & Scalariform & $9.2-10$ & & & & $6.0-6.2$ & $1.6-2.1$ \\
\hline \multirow[t]{4}{*}{ Michelia alba } & Pitted & $8.5-9.2$ & & & & $\begin{array}{c}4.2-5.2 \\
(7.5)\end{array}$ & $\begin{array}{c}1.1-1.6 \\
(4.2)\end{array}$ \\
\hline & $\begin{array}{l}\text { Scalariform-pitted } \\
\text { vessel }\end{array}$ & $26.4-29.5$ & & $\begin{array}{l}2.3-2.5 \\
(7.2-9.6)\end{array}$ & $\begin{array}{l}2.3-2.5 \\
\quad(4.2)\end{array}$ & & \\
\hline & & $19.4-43.7 \times 5.2$ & & & & & \\
\hline & Scalariform & -10.6 & & 14.8 & 2.2 & & \\
\hline \multirow[t]{3}{*}{ Michelia figo } & Spiral & $5.4-5.8$ & & & & $4.7-10.8$ & $2.3-2.5$ \\
\hline & Scalariform & $\begin{array}{c}29.4-31.1 \\
(5.8-6.2)\end{array}$ & & & & $\begin{array}{c}11.3- \\
14.2\end{array}$ & $\begin{array}{c}2.0-2.3 \\
(5.0-8.6)\end{array}$ \\
\hline & $\begin{array}{c}\text { Scalariform-reticular } \\
\text { vessel }\end{array}$ & $35.7-36.2$ & & & & $8.4-11$ & $2.9-3.1$ \\
\hline Amygdalus persica & Scalariform & $24.3-26.2$ & $12-16$ & $\begin{array}{l}12.0-13.2 \\
(13.5-16)\end{array}$ & $\begin{array}{c}3.1-5.8 \\
(3.6-4.0)\end{array}$ & $13.5-16$ & $3.6-4.0$ \\
\hline
\end{tabular}

the lateral walls have perforations, while others do not. In addition, on the outside of some pits, a pit membrane can still be seen (Figure 2(b)). The few pit membranes that remained on the surface of perforations were threadlike, sheetlike, shred-like, mesh-like or band-like in shape (Figures 2(a)-(c)) [14] [15] [16]) Some reticular vessels possess a more acuate tip with very inclined perfora- 
tion plate in the end wall with $17-20$ perforations per plate (Figure 2(d)).

\subsection{Cycas taiwaniana}

Reticular vessels and scalariform-reticular vessels are distributed in the rachis and root (Figure 3(a), Figure 3(b)). Multiple perforation plates were found in the end walls.

In scalariform-pitted vessels, the perforations are elliptical, the length is $8.2-9.4$ $\mu \mathrm{m}$, and the width is $2.8-3.2 \mu \mathrm{m}$ (Figure $3(\mathrm{~b})$ ). The wall of parenchyma cells is like a thin membrane and is not perforated (Figure $3(\mathrm{~b})$ ), indicating that the primary wall are not dissolved to form perforation by enzymes [13]; perforations can be seen only in tracheary elements.
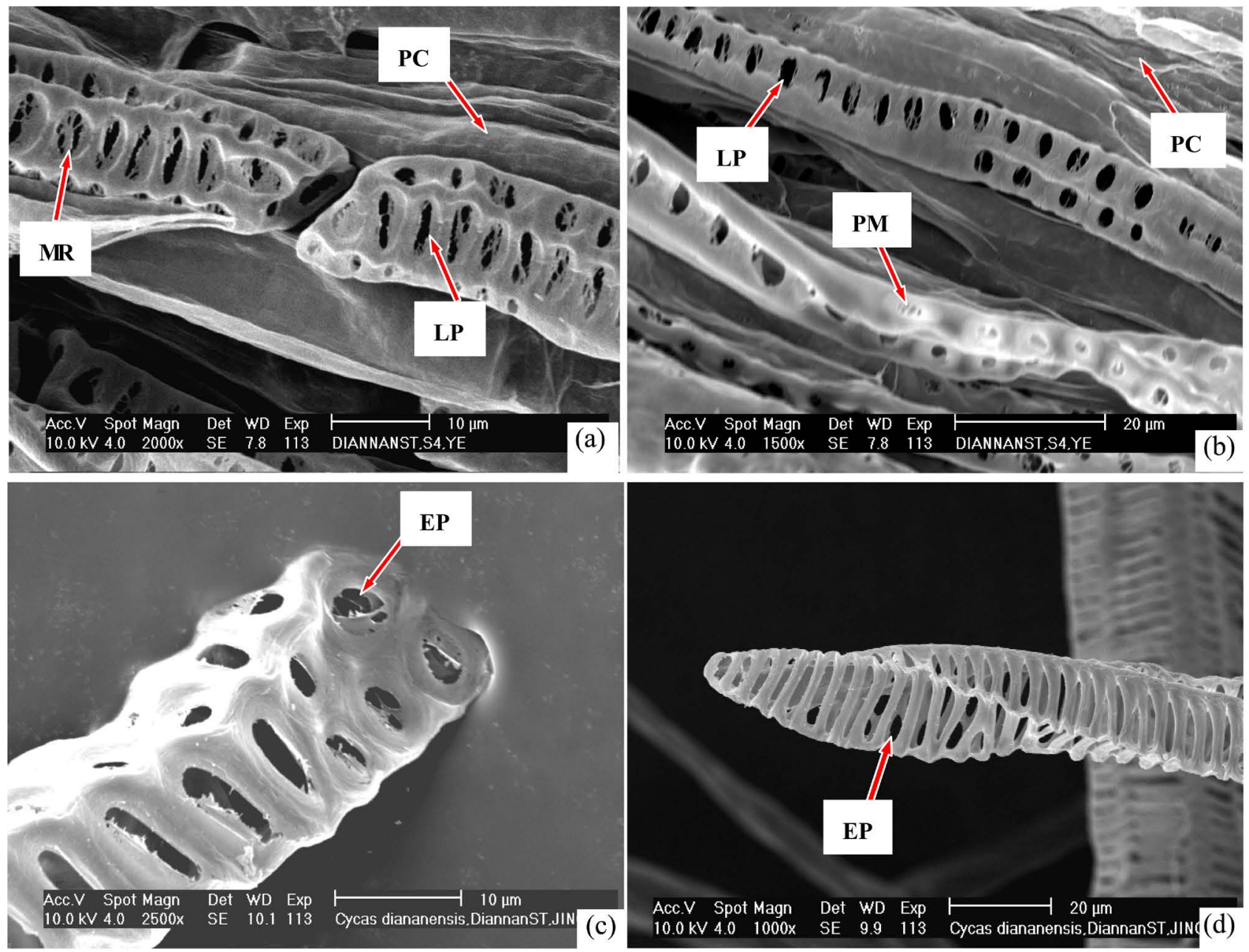

Figure 2. SEM photographs of vessel elements of pinna and stem of Cycas diannanensis. (a) Two scalariform vessel of pinna possess near horizontal or horizontal end wall perforation plate, several perforations in the plate; some lateral perforations formed in the lateral wall, a few of threadlike, sheet-like, shred-like or mesh-like shapes pit membrane remain preserved in the surface of perforation (MR: membrane remnants; PC: parenchyma cell; LP: lateral wall perforation). (b) Several pitted vessel elements of pinna, showing there are some perforations in the lateral wall, and some threadlike and shred-like remnants of primary wall in the periphery of some perforations. Some pits still hold an entire pit membrane in their surface (PM: pit membrane). (c) Scalariform vessel element from stem with horizontal perforation plate of end wall (EP: end wall perforation plate). (d) Reticular vessel element from stem with oblique perforation plate in end wall over the perforations. Ornamentations and perforations in the interior walls are clearly visible. 

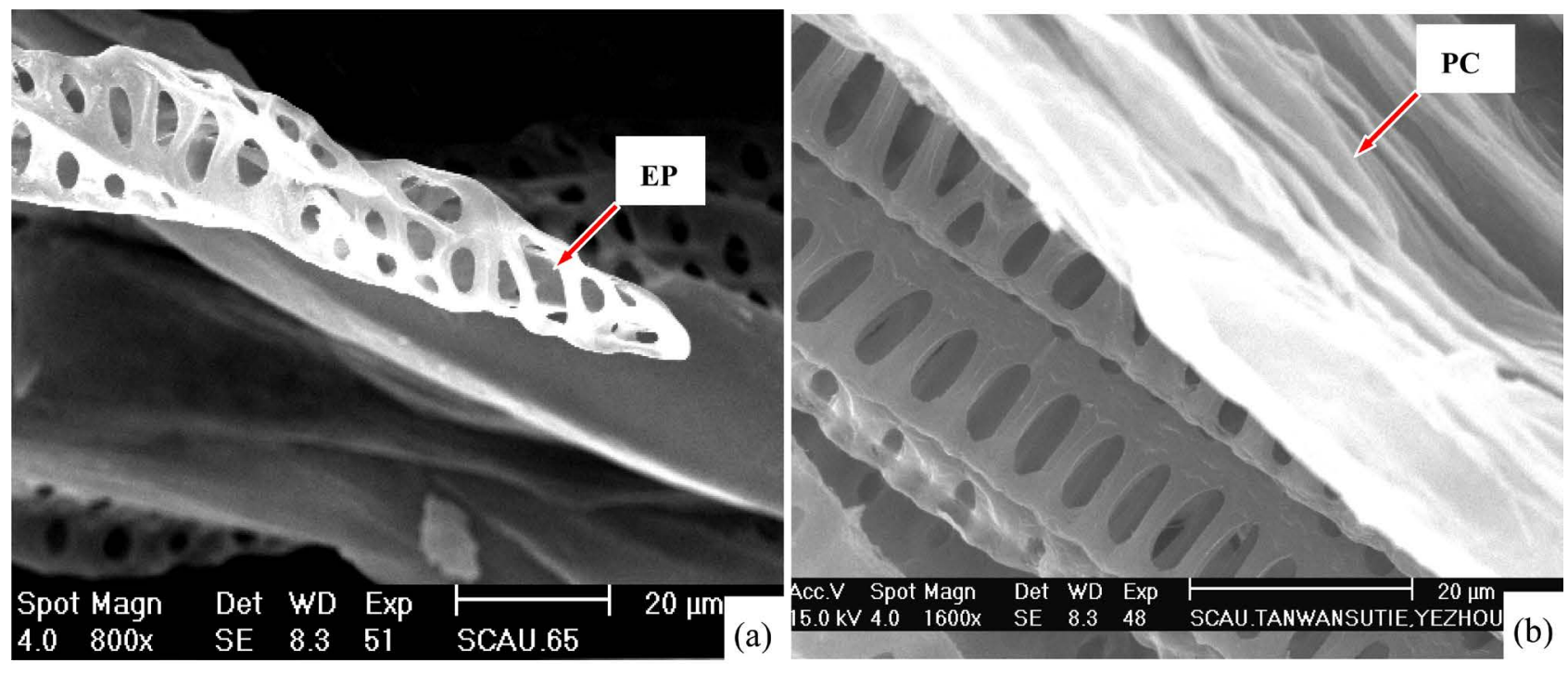

Figure 3. SEM photographs of vessel elements of leaf and root of Cycas taiwaniana. (a) Reticular vessel element of root, with inclined end wall perforation plate with 16 - 22 perforations. (b) Scalariform-pitted vessel elements in rachis, with elliptical perforations in lateral wall (PC: parenchyma cell).

Some reticular vessels have a long, inclined perforation plate for an end wall. Of the 16 - 22 perforations in the plate (Figure 3(a)), some perforations are rather large (Table 1). The extent of inclination is large, so that the end wall is rather difficult to distinguish from the lateral wall.

The diameter and length of these perforations are very large, in these cycad species. The length of perforations in the multiple perforation plates reached 9.8 - $13.6 \mu \mathrm{m}$, their width usually reaching $3.1-4.2 \mu \mathrm{m}$, some even to $5.2-6.0 \mu \mathrm{m}$ (Figure 1(a), Figure 1(e)). In comparison, the diameter of perforations in many angiosperm vessels is only $2 \mu \mathrm{m}$ [17], while they are only $6-8 \mu \mathrm{m}$ long and $3-5$ $\mu \mathrm{m}$ wide [16].

\subsection{Cycas szechuanensis}

The rachis contained annular, spiral, scalariform, reticular, and reticular-pitted vessels, and the diameter of spiral vessels are larger than other species' (Table 1); in all type vessels, the perforations are larger. In this species, the comparative study used the method of hand sectioning [11] [12] with segregation process by dissociated situation, Figures 4(a)-(d) are hand sections; Figure 4(e) \& Figure 4(f) are from the segregation process. Comparing the results of the two methods show no difference in most characteristics, only some differences in some tissues such as parenchyma tissue cells were broken open by the hand sectioning process (Figure 4(a), Figure 4(c)). All vessel elements have completed perforation in their end walls and lateral walls; meanwhile, in some sites of same tissue, there were some web, silk, filiform, shred-like membrane remnants in the perforation surface. These are not like previous observations [11] [12], which state that hand sections can show that all vessel elements have incomplete perforations with some web, silk, or filiform membrane remnants in surface; these characteristics also proved that vessel elements have web, silk, filiform membrane remnants 


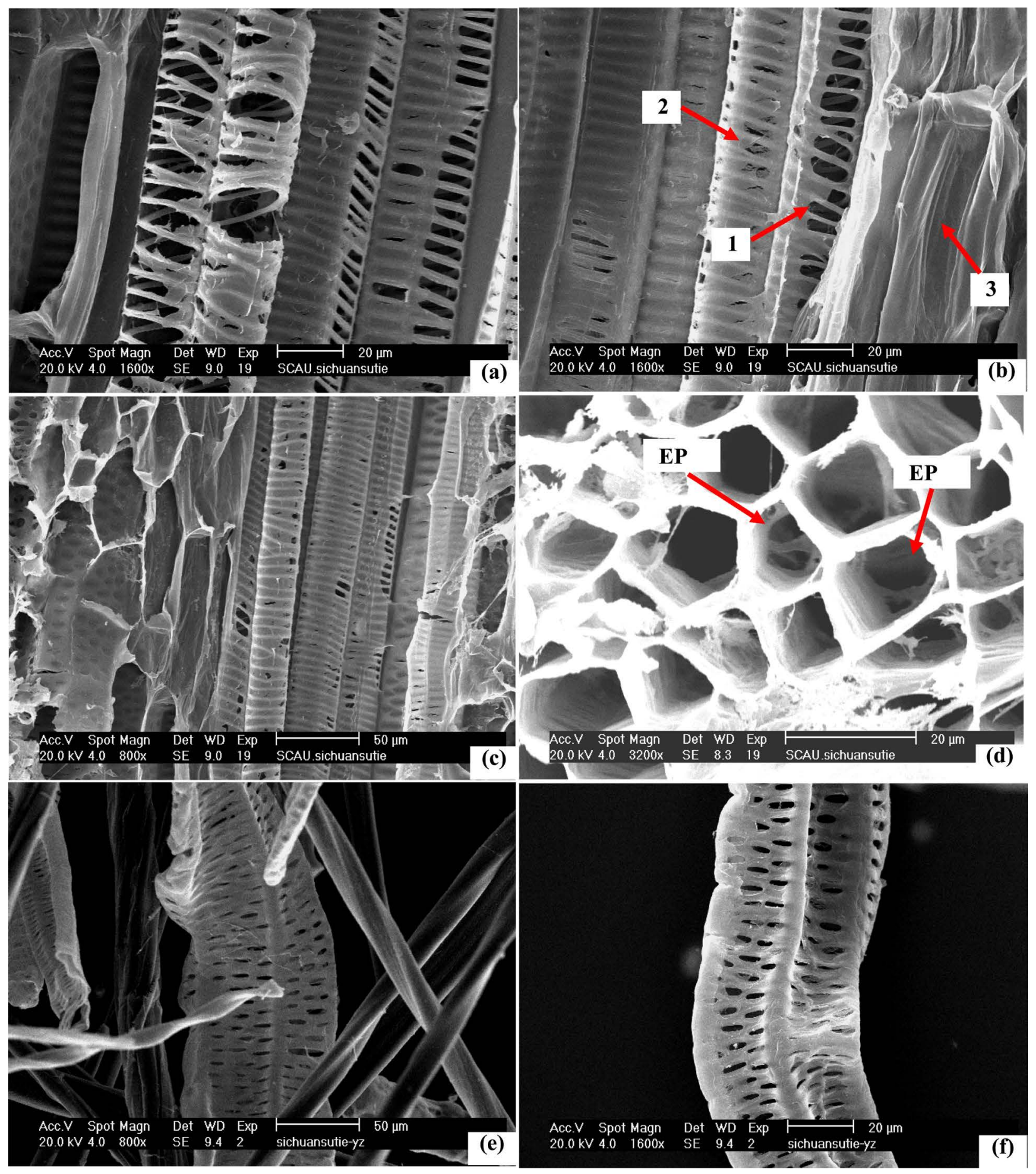

Figure 4. Vessel elements of rachis of Cycas szechuanensis, (a)-(c) The longitudinal section of cut by hand; (d) Cross section of cut by hand; ((e), (f)) The materials of segregation by dissociated solution. (a) Several annular vessel elements, spiral vessel elements, and scalariform vessel elements. Their lateral walls have many large perforations. (b) In this tissue, there are some complete perforations (arrow 1), some incomplete perforations with web, silk, or filiform membrane remnants in their surface (arrow 2) in vessel element walls; these reflect the process of individual development of vessel element (Arrow 3 are parenchyma tissue cells); (c) Several spiral vessel elements and scalariform vessel elements, some perforations in their lateral walls; in their two side, there are some parenchyma tissue cells which have taken open by section process; (d) Cross section of rachis, some larger perforations in end walls and lateral walls though the pipe hole of vessels (EP: end wall perforation); (e) Several pitted vessel elements, there are some perforations in the lateral walls; (f) Two scalariform-pitted vessel elements, their side wall have many perforations, few still contain some web, silk membrane remnants, and others were complete perforations. 
in perforation surface or possessed complete perforations are the characteristics of plant individual development, from the perforations of immature with some membrane remnants, developed to mature perforations which are without any membrane remnants; and are not the characteristics of systematic development.

The rachis cross section (Figure 4(d)) shows some larger perforations in end walls and lateral walls pass through the axis of vessels; In areas not solution processed or touched by the sectioning process, these perforations retain their native features; structural characteristics in such cases are the same as observed via the method that used the segregation process of Jeffrey's. These results further adequately prove that Jeffrey's method is scientific and reliable.

In the cut section method and the isolation solution segregation process, the results are same; all parenchyma tissue cells are without any perforation in their walls. These results further justify also that perforations of vessel elements are the result of plant development, and these perforations are only formed in vessel elements, not formed in other tissues.

\subsection{Metasequoia glyptostroboides}

Pitted vessel elements were primarily observed. Perforation plates of the end wall of some vessels are very near horizontal, with 2 - 4 large perforations having diameters reaching 5 - $6 \mu \mathrm{m}$ (Figure 5(a)). Vessel diameters are $11.2-17.0 \mu \mathrm{m}$. Lateral walls had some perforations, which are large and circular; the diameter of some perforations reached $6.2 \mu \mathrm{m}$ and occupied about $60 \%-65 \%$ of a side of the vessel element, which have a diameter 12.2 - $13.7 \mu \mathrm{m}$ (Figure 5(b)).

Some vessel elements are oblate shaped and have some large perforations in the lateral wall (Figure 5(c). But many more vessel elements are nearly circular or elliptic and had several margins or ridges (Figure 5(a)). In the same tissue, the tracheae had perforations, whereas the parenchyma cells did not (Figure $5(\mathrm{~b})$, Figure 5(c)). Some pitted vessels had a horizontal perforation plate in the end wall, with two perforations in the plate (Figure 5(d)).

\subsection{Chamaecyparis obtusa cv. Tetragona}

In stem material, spiral vessels and scalariform vessels were observed. Because the proportion of secondary walls in the spiral vessel is low, spiral ornamentation was found only inside the vessel; the vessel seemed to be wrapped in a soft membranous layer (consisting of primary wall). In end wall is a simple horizontal perforation plate with a nearly circular or elliptical perforation that occupied most of the plate area (Figure 6(a)). The perforation was $2.8 \mu \mathrm{m}$ long, $2.2 \mu \mathrm{m}$ wide (Table 1).

Like many angiosperm [18] [19], some of the scalariform vessels have large sclariform perforations in the lateral wall reaching 6.0 - $6.2 \mu \mathrm{m}$ long, $1.6-2.1 \mu \mathrm{m}$ wide (Figure $6(\mathrm{~b})$ ). These perforations are so large, that the ornamentation and perforations on the interior walls were very clear.

\subsection{Michelia alba}

In the leaf and stem, there are spiral vessels, scalariform vessels, scalari form-pitted 

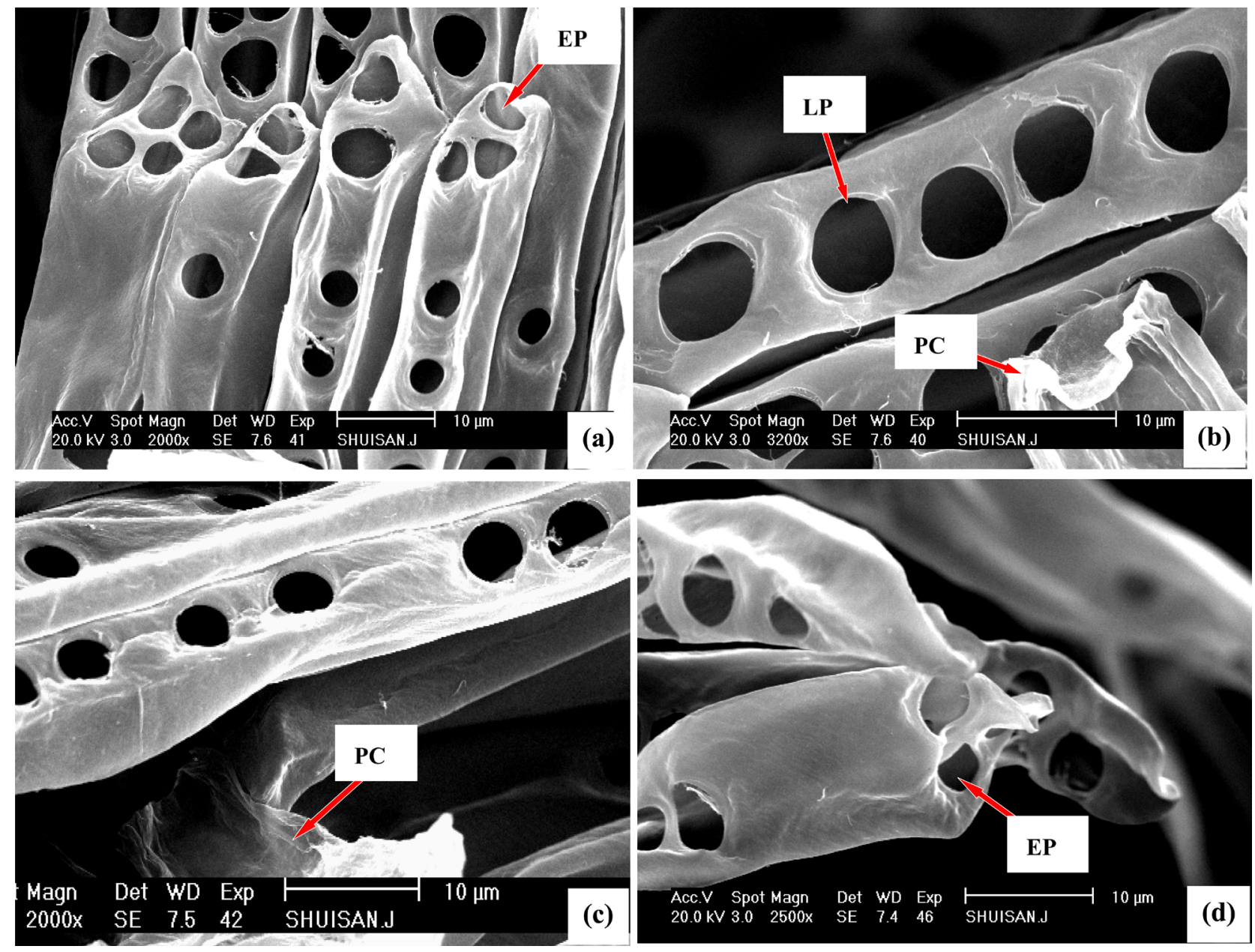

Figure 5. SEM of vessel elements of stem of Metasequoia glyptostroboides. (a) Pitted vessel elements with several near horizontal perforation plates of end wall, 2 - 4 perforations in the plate (EP: end wall perforation plate). (b) Pitted vessel elements with large perforations in lateral wall (LP: lateral wall perforation; PC: parenchyma cell). (c) Oblately shaped vessel elements, with perforations in lateral wall (PC: parenchyma cell). (d) Two pitted vessel elements, one has horizontal perforation plate in end wall with two larger perforations in the plate.
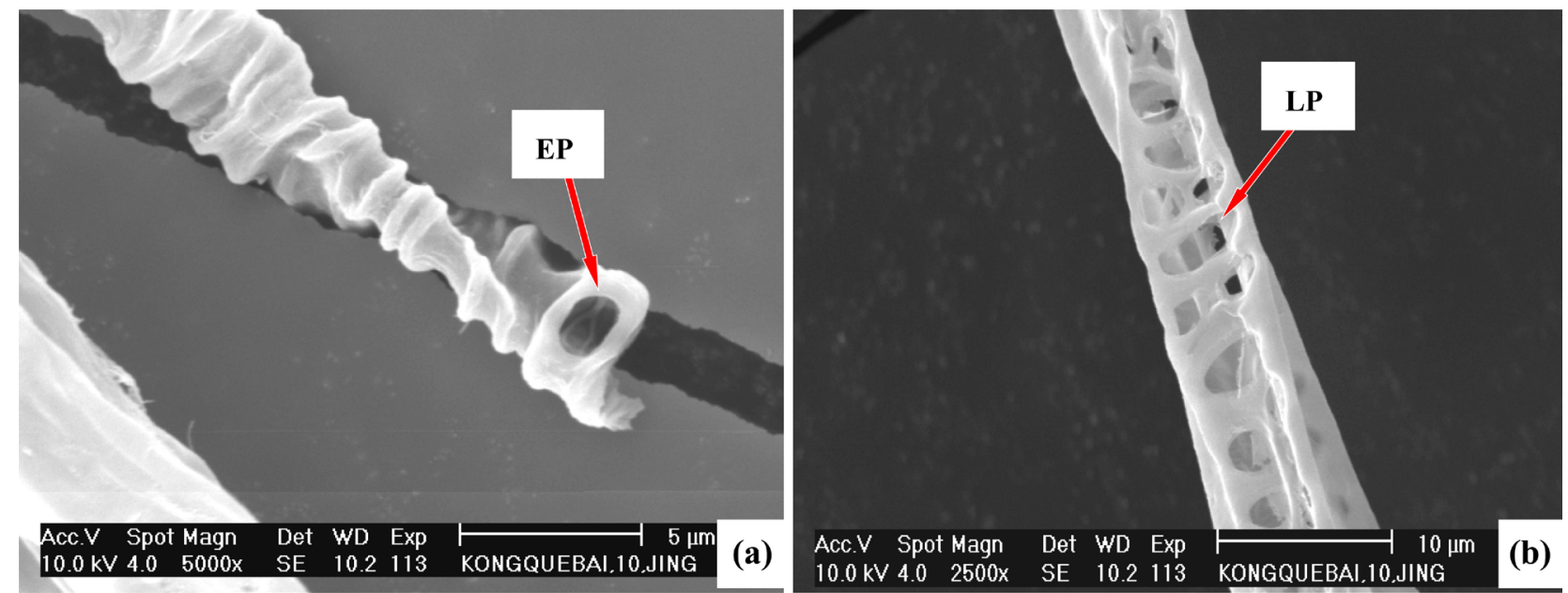

Figure 6. SEM of vessel elements from stem of Chamaecyparis obtusa cv. Tetragona, (a) Spiral vessel element with horizontal simple perforation plate in end wall, a nearly circular perforation in the plate (EP: end wall perforation plate). (b) Scalariform vessel element with large perforations in lateral wall (LP: lateral wall perforation). 
vessels, and pitted vessels. This species is distinct in having many vessel elements that are flat or in a nearly flat, band shape. On some of the scalariform vessel elements, the end is flat like a band, with an acuate, twisting shape, and only a margin at the end (or top), and no end wall (Figure 7(a), Figure 7(b), Figure $7(\mathrm{e})$ ). Some of the vessel elements have an acute tip (Figure $7(\mathrm{a})$ ), while others are flat at the end (Figure $7(f)$ ). Perforations in adjacent vessel elements are in contact with each other only on two sides or on several sides of lateral wall; these end section do not have an inclination plate (Figure 7(a), Figure 7(b), and Figure $7(\mathrm{e})$ ). These characters are more primitive.

Some vessel elements, however, have a plate in the end wall, but it is very sloping and very difficult to distinguish the end wall from the edge of the lateral wall (Figure $7(\mathrm{c})$ ).

Many scalariform perforations can be found in the lateral walls, but some vessel elements formed perforations only in one or two sides (Figure 7(d), Figure $7(\mathrm{e})$ ). Lateral walls lacking perforations still have a primary wall on the surface. In the site there is longer distance to end site, formed many perforations in the lateral wall (i.e. these lateral wall are located in about the middle of the vessel; Figure 7(d), Figure 7(e)). Through some perforations, some ornamentation and large perforations can be seen on the interior wall of the vessels (Figures $7(b)-(d)$ ). Twisted fibers with acuate ends were also seen (Figure 7(e), Figure $7(\mathrm{f}))$.

Pitted vessels have many elliptic perforations in lateral walls (Figure 6(b)). Some pitted vessels have larger perforations that are $7.5 \mu \mathrm{m}$ long, $4.2 \mu \mathrm{m}$ wide. At the periphery of some perforations, a threadlike, membranous remnant of the primary wall is preserved (Figure $7(\mathrm{~d})$ ). Small round perforations in scalariform-pitted vessels have diameters of $2.3-2.5 \mu \mathrm{m}$; oblong perforations are larger (Figure $7(c)$ ). In some places, scalariform vessels have even longer perforations (Table 1).

Some scalariform-pitted vessels are polygonal. Numerous perforations are located in several sides of lateral wall. At the end, there is only a small cupped plate, with a long and narrower perforation to the side (Figure $7(\mathrm{f})$ ).

Comparative the size of these perforations of vessel with vessel elements of cycads, the perforations of cycad are larger, such as scalariform vessels of Cycas taiwanniana, their length of perforation of vessel is $9.8-10.2 \mu \mathrm{m}$, with a width of $2.2-3.1 \mu \mathrm{m}$, specially the perforations of vessel of Cycas diannanensis are obvious large, the length of some perforations arrive $16-18 \mu \mathrm{m}$, with a width of 5.2 - $5.8 \mu \mathrm{m}$, some of them reach $23.2 \mu \mathrm{m}$, and the width is $5.2-6.0 \mu \mathrm{m}$.

\subsection{Michelia figo}

In the materials of leaf and stem, spiral vessels, scalariform vessels, and scalarform-pitted vessels were observed. Some end walls of scalariform vessels are acuate shape, and are without any plate, some tipped with a little blunt shape; the lateral wall has many scalariform perforations (Figure $8(\mathrm{a})$, Figure $8(\mathrm{c})$ ); in a few of perforations, very little pit membrane remain still remains on the perforation; 

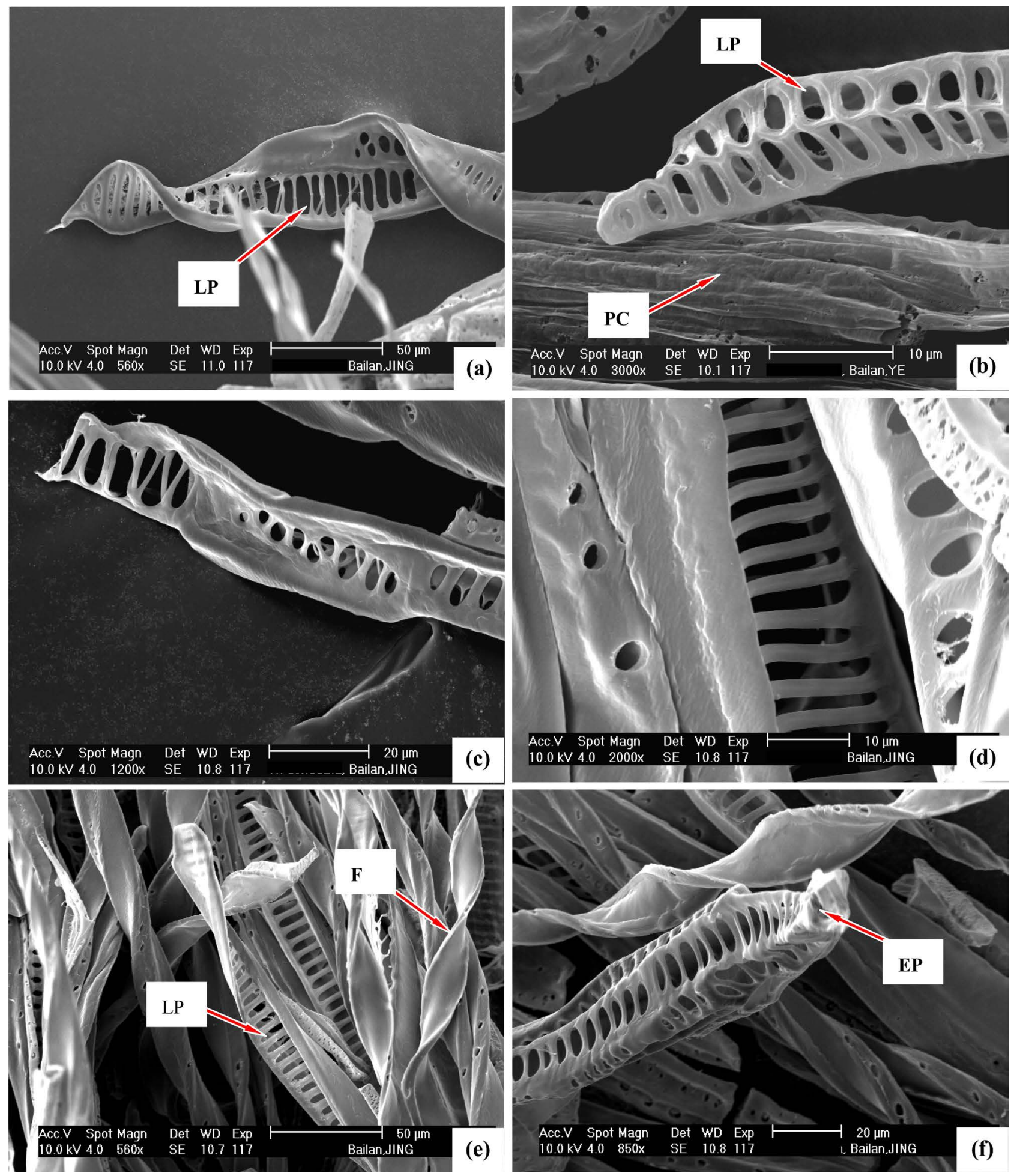

Figure 7. SEM of vessel elements of leaf and stem of Michelia alba. (a) Scalariform vessel elements of stem with perforations only in lateral wall. Flat, twisting, band-shaped vessel elements do not have an end wall, only an acuate margin with a slice (LP: lateral wall perforation). (b) Pitted vessel element of leaf, with elliptic perforations in lateral wall. The end is acuate, without an end wall, only have a marge (PC: Parenchyma cell). (c) Scalariform vessel element of stem, with long, very oblique end wall perforation plate. (d) Scalariform and pitted vessel elements of stem, with perforations in the wall. (e) Scalariform vessel elements of stem. The twisted ends are flat like a band and acuate and lack an end wall. Perforations are on the lateral wall (LP: lateral perforation; F: fiber). (f) Polygonal shaped scalarform-pitted vessel element of stem. Several lateral walls have more perforations than others. Note small, cupped perforation plate on end and long, cabined perforation on the side. 
other perforations have completely differentiated and have formed an integrated perforation. The diameters of the scalariform vessels are $29.4-31.1 \mu \mathrm{m}$, and the perforations are $11.3-14.2 \mu \mathrm{m}$ long and $2.0-2.3 \mu \mathrm{m}$ wide. A few vessel elements have larger perforations in the lateral wall near the end; lengths can reach 11.0 $12.5 \mu \mathrm{m}$, widths are $5.0-8.6 \mu \mathrm{m}$, dimensions like that of perforations in the simple perforation plates of the spiral vessels of Cycas taiwanniana and the pitted vessels of Metasequoia glyptostroboides. The perforations near these large perforations, however, are very small (4.8 - $5.2 \mu \mathrm{m}$ long, 2.1 - $2.3 \mu \mathrm{m}$ wide).

A few of the scalariform vessels have a perforation plate at the tip. Six perforations are present, but the plate is very long and very oblique, so that the end wall is difficult to distinguish from the lateral wall (Figure 8(c)).

Lateral walls usually have more perforations on only one side, while other sides still consist of primary wall and without any perforations (Figure 8(a), Figure $8(\mathrm{c})$ ). Some scalariform-reticular vessels have many perforations in their lateral walls (Figure $8(\mathrm{~b})$ ). Some leptosomatic fibers are twisted with an acuate tip (Figure 8(b), Figure 8(c)).

In leaf materials, spiral vessels and scalariform vessels were seen (Figure 8(d)). Some scalariform vessels are polygonal. Many perforations are distributed in these lateral walls, and the end is a cone, without a plate or any perforations. These scalariform vessels are narrow (5.8 - $6.2 \mu \mathrm{m}$ in diameter), as are the spiral vessels (5.4 - $5.8 \mu \mathrm{m}$ in diameter) (Figure 8(d)).

\subsection{Amygdalus persica}

In the stem, many scalariform vessels were observed. Some end walls of the scalariform vessel elements are very oblique (Figure 9(a)). There are about 12 - 16 perforations in the long (about $58-62 \mu \mathrm{m}$ ) perforation plate, and the tip usually had a little tail. The scalariform vessels have many perforations in the lateral wall (Figure 9(b)). Scalariform vessels are $24.3-26.2 \mu \mathrm{m}$ in diameter. The datum of perforations sees Table 1.

\section{Discussion}

\subsection{The Morphology, Structure of Vessel Element and Evolution}

Compared to the angiosperms, the perforation plate of every end wall of these tracheary elements in Cycadaceae, Taxodiaceae and Cupressaceae is very well developed. They have larger perforations than Michelia alba and M. figo, even larger than those of Amygdalus persica. The spiral vessel elements of Cycas taiwanniana and Chamaecyparis obtusa cv. Tetragona have a large perforation in the simple perforation plate of the end wall. Multiple perforation plates such as the scaraliform perforation plate and the reticulate perforation plate are more primitive, and from these plates, evolve the simple perforation plate with only one perforation in the end wall [18] [19] [20]. Our results showed that some species of gymnosperms have evolved to form a simple perforation plate in the end wall, indicating that the vessels of these gymnosperms are quite evolutionally advanced. 

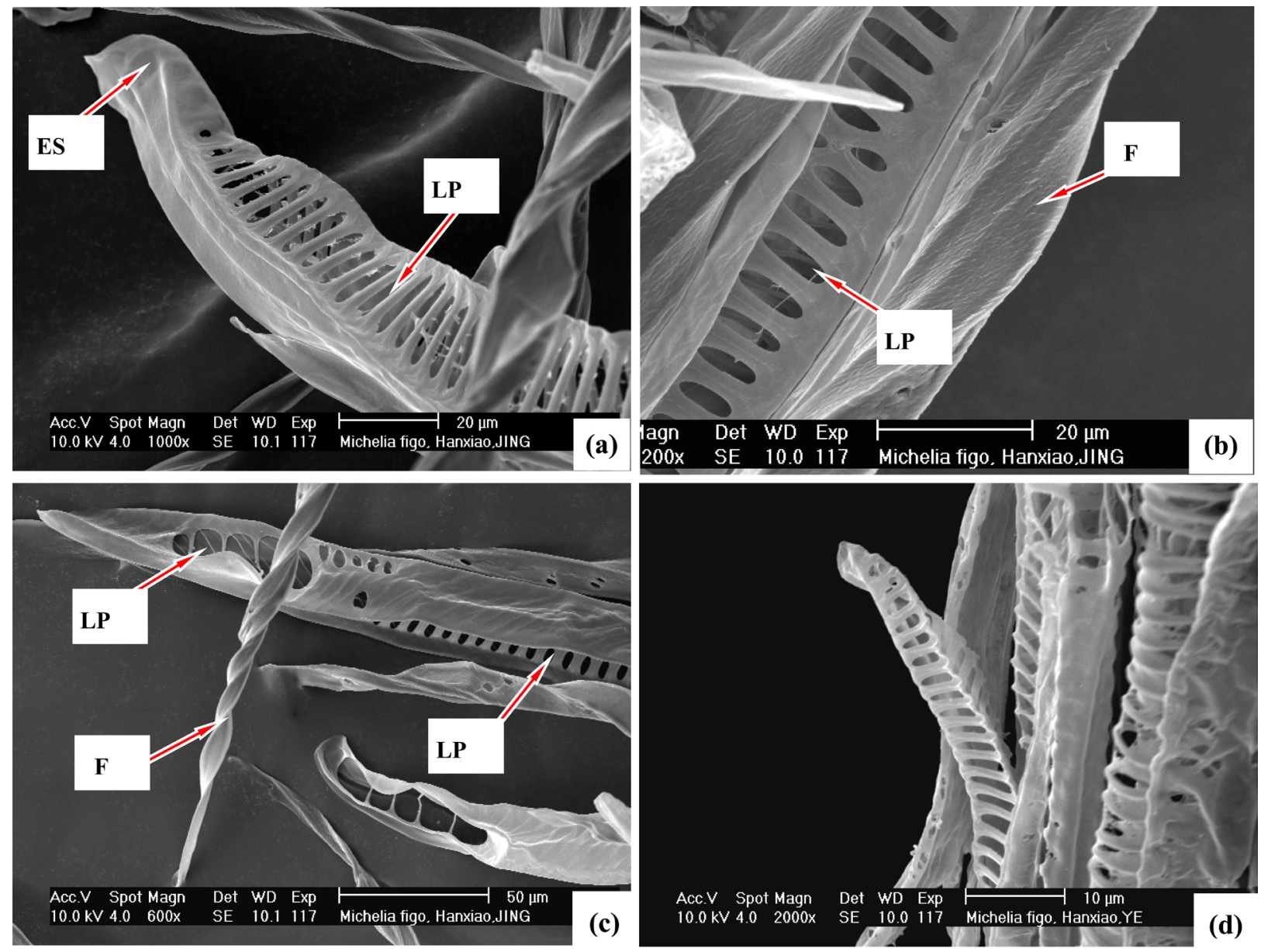

Figure 8. SEMs of vessel elements of leaf and stem of Michelia figo. (a) Scalariform vessel element of stem, with an acuate end wall without a plate. The tip is somewhat blunt. In the lateral wall are many scalariform perforations (ES: end section). (b) Scalariform-reticular vessels of stem, with many perforations in lateral walls (LP: lateral wall perforation; F: fiber). (c) Several scalariform-pitted vessel elements of stem. Vessel element, in upper part of image, lacks a perforation plate in the end wall, which is flat and band-like, and has perforations in lateral wall. Vessel element, in lower part of image, has a long, very oblique perforation plate in end wall. (d) Several spiral and scalariform vessel elements of leaf. Scalariform vessel element is polygonal, with many perforations distribute in these lateral walls, and the cone-shaped end lacks plates and perforations.
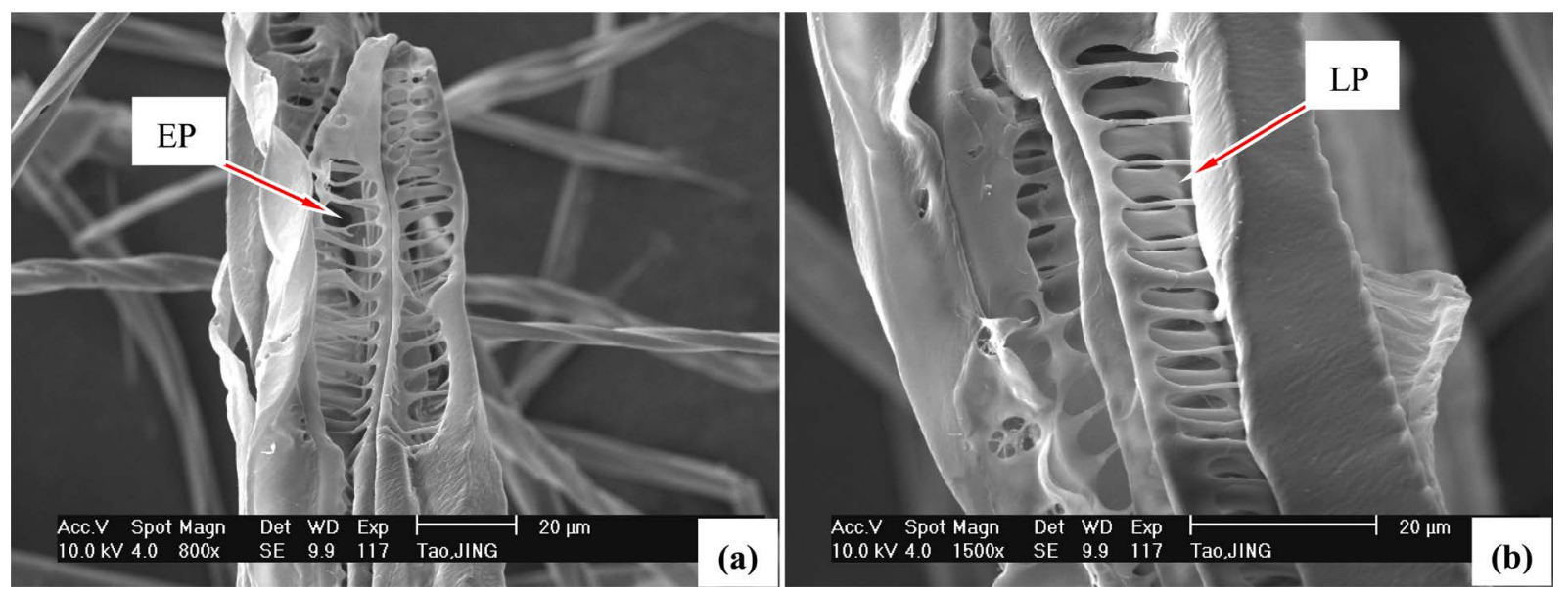

Figure 9. ((a), (b)). Figure 7. SEM photographs of vessel elements of stem of Amygdalus persica. (a) Several scalariform vessel elements, their ends wall were very oblique, there were $13-22$ perforations in the plate. (b) The scalariform vessels, to show the perforations in the lateral wall. 
Some multiple perforation plates in the end wall have several perforations that are quite large. For example, the scalariform vessel of Cycas diannanensis usually has 6 or 7 perforations and some scalariform or scalariform-pitted vessels have 4 - 5 perforations in the perforation plate. In Metasequoia glyptostroboides, the perforation plate usually has 2 - 3 large perforations, a few of them possess 4 perforations in the near horizontal plate; only a few have more than 10 perforations in the plate of the end walls, e.g., the reticular vessel elements of Cycas diannanensis with 17 - 20 perforations and C. taiwanniana with 16 - 22 perforations. In contrast, the vessel end walls of many species of the more primitive angiosperms have dozens or more than 100 or even 200 small perforations [16] [19] [21]. Thus, the structures of the vessels of gymnosperms have evolved more, to favor the rapid transport of large amounts water, as well as inorganic and organic nutrients [22].

According to the general theory of comparative morphology, vessel elements evolved gradually from tracheids, which had ends (bottom or top) that were pointed like a cone. Therefore, one or two lateral walls gradually changed to form nearly a right angle with the interior wall of lateral wall, so the end walls of the more primitive vessels were more sloping and had a distinct, long, pointed tail. Conversely, their vessel elements are more evolved, and their end walls have gradually become horizontal or near horizontal (the end wall forms a $90^{\circ}$ angle or nearly $90^{\circ}$ angle with the interior of the lateral wall) and essentially have no tail [18] [19] [23]. Compared with the vessels of Michelia alba, M. figo, and Amygdalus persica, the vessels of Cycadaceae, Taxodiaceae, and Cupressaceae generally have less inclination in the end wall perforation plate, their end walls are closer to horizontal, and some are horizontal. Michelia alba, M. figo, and Amygdalus persica generally have a long and very oblique end wall perforation plate, and the inclination is so acute, that it is very difficult to distinguish between the end wall and the border of the lateral wall. Thus, these vessels of the gymnosperm genera indicate a more advanced status for this index. These characters exist also in other some cycads and angiosperms [7] [8].

In the past, because observations have been limited to light microscopy, the only focus has been on whether there is a large, single perforation, which resulted from the disappearance of many bars between the small perforations. Ferns have been widely believed to be more primitive, emerging earlier and having more primitive structural characteristics than the cycads, gingko and Taxodiaceae of gymnosperms, thus, they had been assumed to lack vessels in their vascular tissue [24]. But with an increase in research and the use of electron microscopy, vessels were discovered in ferns and gradually in more genera and families that had been thought to be the most primitive taxa, such as Selaginella (Selaginellaceae), Equisetum (Equisetaceae) and more evolved taxa such as Pteridium (Pteridiaceae), and Phyllitis and Marsilea (Marsilaeaceae) [25] [26] [27] [28]. Therefore, like Cycadaceae, Taxodiaceae, and Cupressaceae, woody and tall trees woody possess vessels as a necessity to adapt to environment and natural evolutional phenomenon. 
Generally speaking, ferns have been expected to possess end wall perforation plates and have many more perforations in the lateral wall, with a lateral wall perforation plate that is more developed than some angiosperms [29] [30] [31] [32] [33].

Many vessels of Michelia alba and have no top plate in their end section, only an acute or a line-like margin at the end, meaning that they lack an end wall. The end portion only consists of two wider lateral walls that are flat and band-like, adjoining elements of vessel connect each other rely on only these perforations which locate in these lateral walls, their end is more acute or point and without perforation. These characters are more primitive characters of vessels and very few have been reported in the past [7] [33]. Previously, vessel elements were thought to preserve a very oblique top plate, horizontal or close to horizontal. In fact, there are vessel elements that have no end wall or call top plate as if it is very oblique, adjoining vessel elements by connecting at the perforations in several lateral walls. The vessel element concept is like or approaching a individual tube cell which are open at each end [34], or an elongate, open-ended cell [35]; and vessel element every end possess a or several perforations [18]. The tracheid concept is that tapered cells, with overlapping ends and often spiral thickening of cell wall, rather than being open-ended, perforations [35], tracheid is no perforation cells [18]. The character which differentiates vessel elements and tracheid elements is whether it possesses perforations in the end wall. Vessel elements which have a perforation in end walls certainly are not vessel elements, as they have an "end wall". In fact, many vessel elements like in Michelia alba are without end wall, and only have two lateral walls and a margin, like a flat band, those perforations located in lateral wall approach the end, and can be thought of as the end. These vessel elements can then still have a large capacity for conduction, even exceeding that conferred by having only a top plate in the end wall as a result of the several surfaces of the lateral wall and the more numerous or larger perforations. Furthermore, the structure can serve a more important function than a vessel element by connecting two or more vessel elements in a longitudinal direction. In this way, even if these features are more primitive in their structure, they are still preserved in more advanced plants such as angiosperms.

The research showed that some vessel element of Michelia alba of angiosperms and cycads possess a twisting shape, that can enable several adjoining vessel elements to connect together. Thus, such a structure improves conduction and confers greater mechanical support at the same time.

In this study, perforations were seen only in tracheids, the cell wall of parenchyma cells only had primary walls without any perforations, indicating that enzyme action has specificity for tracheary elements and not dissolve parenchyma cells, whereby they can preserve the integrity of the thin membrane-like wall.

Seen from these figures of all species in our research, in these vessels, some sites have perforations and other sites have no perforation in the same vessel element, those sites consist of primary wall located in vessel surface. These results showed that perforation formed and differentiated have special site and 
function.

Furthermore, in some vessel elements, only a large perforation is formed in the end wall, however, its lateral wall has not any perforation (Figure 6(a)). Otherwise, all cells of parenchyma tissues are all without perforation in their any walls (Figure 2(a), Figure 2(b); Figure 3(b); Figure 5(b), Figure 5(c); Figure $7(b))$. And our observations have a peculiarity, that in any species of plant, there are perforations in all end or end walls, some end walls have no perforation, only lateral walls have perforation (except some vessel element of Michelia alba which only has a margin at the end and no end wall). Even if some vessel elements are without any perforation in the lateral wall, their end walls also possess perforations (Figure 6(a)). These results demonstrate that the end walls of vessel elements certainly possess perforations, and the site of perforations formed are selective. These characters showed that forming of perforation is a phenomenon of adapt to transport function of plant which formed in some especially places of vessel, and it not form randomly in any tissue or any place.

\subsection{The Measures of Research Vessel Elements and Tracheid Elements Analysis}

These characters studied here also demonstrate that the experimental methods are stable and scientific. Furthermore these characters testify that like very few prior workers [11] who surmised that the pit membranes consist of primary wall which may easily be damaged in procedure using Jeffrey's method (10\% nirtric $10 \%$ Chromic acid, 1:1) are perhaps wrong. Because this method has been through many replications, and showed to be stable and reliable, it does not damage pit membranes, so, since 1940, this important method [36] is widely utilized to study vessel element structure including angiosperms, ferns, gymnosperms. Most vessel research uses this method, only a few studies used other methods such as sodium hypochlorite in dissociated solution. These are among the strongest oxidizers, with oxidized intensity higher than Jeffrey's method solution. It should and must be noted, in these solution of several experimental methods, the solution of Jeffrey' method is most moderate. And that the method procedure require low than $60^{\circ} \mathrm{C}$, and stop isolation (maceration) then the tissues have begin separated, this is most safe and stable method.

Our research results showed that perforations were seen only in tracheids, the cell wall of parenchyma cells only had primary walls without any perforations in the same view, it proved enough that Jeffrey's solution may not damage primary walls which are parenchyma cells walls, and the composition of pit membranes. In other words, if Jeffrey's solution may damage primary wall that which shall be damaged all cells wall randomly in any tissue, so that tracheary elements and parenchyma cells walls all shall form many perforations. But this is not observed.

If who make a so-called evidence want to testify that Jeffrey' method is mistake, that who certainly is not in the light of the procedure of Jeffrey method, he certainly is used a such as overpass $100^{\circ} \mathrm{C}$ situation, and after tissues have separated, he deliberate still continue long term isolation, but, this is not Jeffrey's 
method, and is a deliberate distort and sabotage action to the method.

In the research of Carlquist and Schneider [11], measured which materials were cut sections 1 - $2 \mathrm{~mm}$ thick by hand, then fixed in aqueous $70 \%$ ethanol, and were air dried on a warming table, exhibited those figures which tracheary elements have many reticulate or porose pit membranes in ferns, because they thought that their earlier studies on fern xylem were based on macerations prepared with Jeffrey's fluid. Macerations of dicotyledonous woods and even of xylem of monocotyledonous roots and stems [29] [37] tend to leave pit membranes in lateral walls of vessel elements intact; they therefore assumed that these methods would result in similar results with fern xylem. That assumption proved faulty because fern roots and stems are refractory when treated with Jeffrey's fluid. Successful macerations require prolonged treatment, apparently because the xylem is associated with thick fibrous sheaths. Although secondary wall architecture was not damaged by prolonged maceration, but they believe that the integrity of primary walls was lost to various degrees by prolonged oxidative treatment. As such, Carlquist and Schneider (2007) [11] believed that revisions in their earlier reports are therefore required. Certainly presence of porous pit membranes, reported in their earlier studies, has been confirmed in this study, although with improved preservation and imaging. However, reports of multiple perforation plates, lateral perforation plates, and intermittent perforations in fern tracheids should be regarded as erroneous. Reports of perforation plates lacking any pit membrane remnants in such genera as Microgramma and Vandenboschia [30] may be the result of excessive maceration.

But seen to their figures of the research which were treated by macerations [30], their figures of experimental results had a very typical character because of artificially excess treated, so that all pits in tracheary tissues were shaped perforations in all cell walls, these specimens are without any pit membrane was integrated. Their study had not the situations that all end walls possessed perforations and only a part of sites of lateral walls have perforations, and other some sites were without perforation with there were integrated primary wall (without any reticulate or porose pit membranes). Thereby, their research result maybe was an excess treatment by maceration solution. Otherwise, they did not exhibit the pictures of cells of parenchyma tissues, and were without any a picture which was that the cells of parenchyma tissues together with tracheary elements, if they so excess treat, should had induced to these cells of parenchyma tissues formed perforation at the same time, but they did not notice this content.

They thought that their this measure [11] which were cut sections 1 - $2 \mathrm{~mm}$ thick by hand, using single-edged razor blades. Then fixed in aqueous $70 \%$ ethanol and air dried on a warming table was mild, this is not sure. Because they only exhibited tracheary elements, and was without exhibit cells of parenchyma tissues, the cells of parenchyma tissues possible had possessed porose or reticular wall. Because the materials with ethanol dried in air is not mild, because ethanol volatilizing quickly it easy make material quickly contract and drag, or transmutation. Thereby, almost all scholars to use the new measure that dehydrated in a 
graded series of ethanol and isoamyl acetate and critical point-dried in $\mathrm{CO}_{2}$, because this measure is really mild.

Otherwise, their sections from hand used reamer was very easy formed damage to the primary wall that take off the materials of primary wall, those materials of primary wall shall be sticked in reamer, and be peeled off, then these sections put in $70 \%$ ethanol solution, they formed like uniformity porose or reticular primary wall (pit membrane of tracheary element) at once like their figures [11]. These are very deserve oppugn and more exploration. They thought also that artifacts, such as tearing or cracking of pit membranes, are readily recognized as stress-induced phenomena. Pit membranes that are "striated" (minutely corrugated) occurred both in their earlier studies and in the study [11] (Figure 3, upper left) and very likely resulted from kinds of stress, such as heating by the SEM electron beam. Such stress artifacts are easily recognizable as different from the reticulum of pit membranes that results from natural hydrolysis of the cell wall [11].

But this is ungrounded, because if primary wall can be heated by the SEM electron beam so that formed perforation, the process which is hit form perforation shall certainly can be seen, because that is impossible occurred that then trachaery element entried the field of vision of SEM, at once all are heated to artifact perforation in split second, they certainly having a changing process can be watched by observer. In our many researches, we were all without seen the phenomena.

Moreover, those materials of plants had were sputter-coated a layer gold membrane in their outside, therefore they were firmly fixed and safeguarded, thereby they complete could not be heated formed perforation by SEM.

Otherwise, it is none any proof showed that why heating by the SEM electron beam stress only locate in tracheary elements, and they were heated formed perforation in primary wall (pit membrane), whereas, those walls of parenchyma tissues cells which consist of only primary wall were not heated formed perforation. Because our researches showed that the surface of primary wall in many of tracheary elements of plants where have not perforation formed are same integrity, thickness and smoothness as parenchyma tissues, there are without any porose or reticulate phenomena, only a part of sites have perforations in the wall of vessel elements.

Moreover, many treated materials of plant by other methods, are not needed observation by SEM, and are enough only observed by light microscope, this is a condition without any heating by the SEM electron beam stress, those perforations of natural formed in end walls and some lateral walls can be observed same as in SEM. In light microscope, light ray came from underside, thereby, the sites of perforation are bright, those sites are distinctness differentiate to there are without perforation and possessed integrated primary wall.

Any vessel element are all need pass through the individual development process that it from the shape which is without any wall perforation, to the shape which wall(pit membrane)have retained thread-like, sheet-like, shred-like or 
mesh-like membrane remnants of the primary wall in the periphery of the perforations. With some not complete perforations, these remnants are evidence that the primary wall gradually developed small or more than a half perforations, and eventually these wall remnants completely disappeared, leaving large, entire perforations. As these perforations differentiated, the dissolving membrane remnants were reabsorbed by the plant, until the membranes completely disappeared, then developed to the shape that possessed some or many complete perforations. This is a vessel individual development phenomena; in this research, in same tissue of vessel elements of some species, there were some complete perforations which have differentiate mature in some sites; meanwhile, some incomplete perforations with some mesh-like, shred-like and filiform membrane remnants in other sites (Figures 2(a)-(d); Figure 4(a), Figure 4(b), Figure 4(f); Figure 8(a)); these results justified also that this is a individual development process. These are not like the formers [11] [12] said that then used the method which is cut section by hand, should can seen only that all vessel elements are the situation which all perforations are incomplete with some web, silk, filiform etc membrane remnants in surface; and are not as former said that they are only the characteristics of systematic development [11] [12].

Therefore, they [11] [12] take a very little partial sites pictures which immature tracheae element wall only have web, silk, filiform remnants and not expressed the characteristics of other sites where were have developed mature vessel element, therefore said that this is a systematic development phenomena, and said that this species is without complete perforation, it is at the status which tracheid prepare develop forward vessel. This is also subjective and error.

Thereby, we thought that their hereinbefore parlances have many errors, and are a subjective guesswork.

In this research, we used the method as the literature [11] [12], it is without any dissociated fluid, seen the structural characteristics of rachis of Cycas szechuanensis (Figures 4(a)-(d)), all longitudinal section and cross section were the situation that perforations exist in tracheary elements and without perforations in parenchyma cells, especially the cross section (Figure 4(d)), can observed some larger perforations located in end walls and lateral walls inside vessel pipe hole; in these places, where are without go through any dissociated situation, and are without any touch by tool in the process of sectioning by hand, therefore, these perforations are most pure natural situation; these structural characteristics are same as the method that used the isolation process of Jeffrey's. These results also further adequately proved that Jeffrey's method are scientific and reliable.

In this research, seen the cross section of rachis of Cycas szechuanensis (Figure 4(d)), can observed some larger perforations in end walls and lateral walls through the pipe hole of vessels; in these places, where are without go through any dissociated situation, and are without any touch by tool in the process of sectioning by hand, therefore, these perforations are most pure natural situation; these structural characteristics are same as the method that used 
the isolation process of Jeffrey's. These results also further adequately proved that Jeffrey's method are scientific and reliable.

On the question, some scholars have already made a specialized comparative experimental study [38], They to the secondary xylem from five woody species used as follow several methods made experiment: (1) The fresh materials were cut sections $1-2 \mathrm{~mm}$ thick by hand [11], in low vacuum and then the same materials were air-dried and examined both in low- and high-vacuum with SEM. (2) The fresh materials were fixed in 70\% ethanol, FAA, and Karnovsky' s Fixative, and examined which were cut sections 1 - $2 \mathrm{~mm}$ thick by hand, with SEM in low-vacuum respectively [11]. (3) Smooth surface on the materials were made by using the technique of paraffin section and then the materials were examined in high-vacuum with SEM. (4) The materials were treated by Jeffrey's Fluid and observed in high-vacuum with SEM. The results showed that the pit membrane in the pits and the remnants in the perforation and the structural characteristics of perforations were not notably different with that in different processing and handling as well as in low- and high-vacuum. The description of the pit membrane and its remnant and perforation based on the SEM observation is validly claimed.

Otherwise, other scholars carried out comparative studies used the paraffin section method with Jeffrey' s method, for avoiding the treatment of isolation solution, researched the structure of vessel elements about more than 10 families plants, the result showed that those vessel element same as which were treated by Jeffrey's fluid, the results showed that there were many perforations in the end walls and lateral walls of vessel, and the their size were larger and have many completed perforations [39]; these reports was not like the situation which said by Carlquist and Schneider [11] that only could observed the pit membrane like web, silk, filiform etc. shape in the perforation surface. These results are all proved that Carlquist and Schneider' [11] report have errors, they only observed the very little partial place in wall of vessel element, or only chose the characters which some pits or perforation possessed like web, silk and filiform etc. shape membrane remnants in the surface to made pictures and described, therefore, other places which possessed whole perforations in the wall of vessel, they not observed and not described. So, the first, although their so-call new measure is a simple and crube, but it was also could basic be used, but the effect is lower than other measures; the second, their reports in several papers which were without any whole vessel element or more proportion of a vessel element can be viewed to the all vessel element' or more places and perforations by reader, only were some very partial sites which have only one or several pits. So their measures and thought [11] [12] are more subjective, on-sidedness and errors.

Because primary walls of every tracheary element wrap in most periphery of the cell, afterward the secondary wall of lignification and suberinization formed inside the primary wall, and formed various ornamentations (such as spiral, annulur, scalariform shapes) on the interior layer of the primary wall. If the tracheary element is a pitted tracheid or vessel element, the pit cavity of simple or 
bordered pits that are formed by secondary wall are located in inside primary wall, the surface of tracheid or vessel element have not pit or pore as entrance, because these pits peripherally wrap a layer membrane of primary wall [18] [23] [40] [41]. Between two adjoining tracheary elements is an intercellular layer (middle lamella) of pectin, and the two tracheary elements separate from this layer during an experimental treat [9] [10]. Therefore, a perforation in the tracheary element is seen as a dark, deep hole with the scanning electron microscope (SEM). If there are no perforations, the primary wall will still wrap in the cell surface, and the wall structure will be bright and preserved with a smooth surface. The results of the present research completely conformed to these theories.

\subsection{The Analysis on the Sizes of Vessel Element and the Perforation}

According to the theory that underlies comparative morphology, vessels with smaller diameters are more ancestral and primitive characters (Yu, 1954 [42], 1981 [43]; Zhou and Jiang, 1994 [44]; Wang et al., 1996 [45]). In the present research, the diameter of vessel elements of cycads and two genera of other angiosperm are the same size, even though many vessels, such as the scalariform, reticular, and pitted vessel elements of Cyas diannanensis, are larger than those in angiosperms; the diameter generally reaches $22-30 \mu \mathrm{m}$, and many reach $40-$ $46 \mu \mathrm{m}$, larger than any of the vessels in the three genera of angiosperms studied here. In some of the smaller vessel types in the cycads, e.g., the pitted vessel of Cycas diannanensis, the diameter ranges from 14.6 to $15.8 \mu \mathrm{m}$, and the diameter of pitted vessel of Metasequoia glyptostroboides is $11.2-17.0 \mu \mathrm{m}$; the diameter of scalariform vessel of Chamaecyparis obtusa cv. Tetragona is $9.2-10 \mu \mathrm{m}$; whereas, some diameter of pitted vessels of Michelia alba is only $8.5 \mu \mathrm{m}$, in Michelia figo; the diameter of some sclariform vessels is small, only $5.8-6.2 \mu \mathrm{m}$, and the spiral vessels are generally small; the diameter is $5.4-5.8 \mu \mathrm{m}$, therefore, accounts for the extent of evolution of these gymnosperms and angiosperms are near or same in the index.

The large perforation in vessels is an evolutionary character indicating that vessels are more developed [19]. Comparative analysis of the size of perforations showed that the diameter and length of cycads were very large, such as in simple perforation plate of end wall of annular vessel, the diameter of a circular perforation had approached $8 \mu \mathrm{m}$, and the length of perforations which located in multiple perforation plates had reached $9.8-13.6 \mu \mathrm{m}$, their width could reach $4.1-4.25 \mu \mathrm{m}$, even some widths reach $5.2-6.0 \mu \mathrm{m}$; the length and width of $C$. szechuanensis had reached $20-35$ and $15-18 \mu \mathrm{m}$ in annular and spiral vessel elements, and $16-18$, and $6-10 \mu \mathrm{m}$ in scalariform vessel elements. Compared with many angiosperms, which have vessel perforations that are only $2 \mu \mathrm{m}$ in diameter [17], 6 - $8 \mu \mathrm{m}$ length, and 3 - $5 \mu \mathrm{m}$ width [16], cycad vessels have larger perforations.

Compared with the perforations of vessel of Cycadaceae, Taxodiaceae and 
Cupressaceae with angiosperms, the perforations' length of pitted vessel in $\mathrm{Mi}$ chelia alba is $4.2-5.2 \mu \mathrm{m}$, with a width of $1.1-1.6 \mu \mathrm{m}$; it is obviously smaller than in cycads; in scalariform-pitted vessels of Michelia alba, their diameter of some little round perforations is $2.3-2.5 \mu \mathrm{m}$; these sizes are even obviously smaller than the size of vessels' perforation of Metasequoia glyptostroboides which diameter is $6-6.2 \mu \mathrm{m}$ and the size of perforation of Chamaecyparis obtusa cv. Tetragona which diameter of circular perforation is $4.0-4.2 \mu \mathrm{m}$, or near oblong size of scalariform perforation which length can reach $6.0-6.2 \mu \mathrm{m}$, with a width of $1.6-2.1 \mu \mathrm{m}$ (total area of perforation is larger). Although some pitted vessels possess larger perforations, their length of perforation is $7.5 \mu \mathrm{m}$, the width is $4.2 \mu \mathrm{m}$, and those oblong perforations of vessel of $M$. alba are larger; the lengths reach $7.2-9.6 \mu \mathrm{m}$, with a width of $4.2 \mu \mathrm{m}$; even a part of scalariform vessel possesses larger perforation; the length is $14.8 \mu \mathrm{m}$; the width is $2.2 \mu \mathrm{m}$, however, their size is still smaller than cycad's (total area of perforation).

Even if the length of perforation of scalariform vessel in M. figo is $11.3-14.2$ $\mu \mathrm{m}$, with width $2.0-2.3 \mu \mathrm{m}$, some of them are larger; the length can reach 11.0 $12.5 \mu \mathrm{m}$; the width is $8.4-11 \mu \mathrm{m}$ (a large width), and some perforations' length of $A$. persica is $12.0-13.2 \mu \mathrm{m}$, with a width of $3.1-5.8 \mu \mathrm{m}$; the length of perforations of scalariform vessel is 13.5 - $16 \mu \mathrm{m}$; the width is $3.6-4.0 \mu \mathrm{m}$, but their sizes are all smaller than some perforations of cycads' vessel, such as Cycas diannanensis, their length of perforation is $16-24.1 \mu \mathrm{m}$, and the width is $5.2-6.0$ $\mu \mathrm{m}$.

Like many angiosperms, Michelia alba, M. figo and Amygdalus persica and the species of cycad, Taxodiaceae and Cupressaceae, have vessel elements with lateral walls that possess perforations, and these perforations link between vessel elements at side surfaces, so that these elements not only communicate and transport fluids longitudinally, they also transport inorganic and organic nutrients in a transverse plane [18] [41]. This is seen, for example, in the perforations of the lateral wall of tomato (Lycopersicon esculentum) [46]. This vessel structure seems to be adapted to meet the demand of every portion of tissues of these plants for the transport of large amounts of materials essential for metabolism.

Su et al. [47] have discovered vessels in Pinus tabulaeformis, Pinus sylvestris, it further shows that possessing vessel in xylem should be a pervasive phenomenon in gymnosperms.

Vessels evolved from tracheids, and in the process have formed numerous perforations in the end and lateral walls and enable transport of much more water and nutrients (about several ten times, some plants leaves are about 50 times, in woods, it is about 100 times) than tracheids within a given time [20]. Our research of vessels in these species of Cycadaceae, Taxodiaceae and Cupressaceae and comparison with structural characters of vessels in two families of angiosperm, are evidence of levels of the evolution of tissue structure in these gymnosperms. It is important to further understand the mechanism by which these primitive seed plants have been able to endure environmental challenges such as 
drought, extreme heat and glacial periods and thereby, reveal their secrets for survival and procreation.

\section{Acknowledgements}

This project was supported by the National Natural Science Foundation of China (Grant No. 30260007 and 30410203270). The authors thank Chia-jui Chen, the President of the Cycad Society of China; William Tang, IUCN specialist, USA, Dept. of Agriculture; Dr. Jin-shuang Ma, Brooklyn Botanic Garden, New York, USA, the vice presidents of the Cycad Society of China, Dr. Nan Li and Professor Nian Liu, for supplied cycad materials and support; engineers Xun-cao Pan and Xin-fang Chen for help with electron microscopy.

\section{References}

[1] Hu, Y.F. (1995) Discoveries of Some Reproductive Organ of Fossils of Cycads in China and on the Origin of Cycads. Chinese Bulletin of Botany, 12, 43-48.

[2] Huang, Y.Y. and Zhang, H.D. (1999) The Brief Report on Discovery of Vessel in Cycads. Journal of Guangxi Agricultural and Biological Science, 18, 161-162.

[3] Lin, J.Z. and Huang, Y.Y. (1999) Discovered Vessel in Cycads Again. Journal of Guangxi Agricultural and Biological Science, 18, 332-335.

[4] Huang Y.Y. and Wei, L.J. (2004) Discovered Vessel in the Plant of Stangeriaceae of Cycadopsida. Journal of Guangxi Agricultural and Biological Science, 23, 86.

[5] Huang, Y.Y. and Liao, W.B. (2004) Primary Report on Discovering Vessel in Plants of Coniferae and Taxinae. Acta Scientiarum Naturalium Universitatis Sunyatseni, 43, 125-128.

[6] Huang, R. and Wu, J. (2007) Vessels Discovered in Cycas panzhi huaensis L. Zhou et S. Y. Yang. Journal of Sichuan University (Natural Science Edition), 44, 430-433.

[7] Huang, Y.Y., Liao, W.B., Zhang, H.D., Wang, J.Z. and Wu, Y.H. (2008) Comparative Studies on Structural Feature of Vessels of Four Genera of Cycads with Angiosperm. Acta Scientiarum Naturlium Universitatis Sunyatseni, 47, 77-86.

[8] Huang, Y.Y., Liao, W.B., Zhong, X.Q., Wei, L.J., Zhang, H.D. and Lu, Y.F. (2010) Structural Characteristics of Vessels in Three Families of Cycadopsida. Journal of Life Sciences, 4, 1-15.

[9] Li, Z.L. (1987) Technique of Plant Microscopic Mount. 2nd Edition, Science Press, Beijing.

[10] Zheng, G.C. and Gu, Z.P. (1993) Biomicrological Technique. 2nd Edition, Higher Education Press, Beijing.

[11] Carlquist, S. and Schneider, E.L. (2007) Tracheary Elements in Ferns: New Techniques, Observations, and Concepts. American Fern Journal, 97, 199-211. https://doi.org/10.1640/0002-8444(2007)97[199:TEIFNT]2.0.CO;2

[12] Schneider, E.L., Carlquist, S. and Chemnick, J.G. (2007) Scanning Electron Microscope Studies of Cycad Tracheids. South African Journal of Botany, 73, 512-517.

[13] Aspeborg, H., Schrader, J., Coutinho, P.M., Stam, M., Kallas, Å., Djerbi, S., Nilsson, P., Denman, S., Amini, B., Sterky, F., Master, E., Sandberg, G., Mellerowicz, E., Sundberg, B., Henrissat, B. and Teerl, T.T. (2005) Carbohydrate-Active Enzymes Involved in the Secondary Cell Wall Biogenesis in Hybrid Aspen. Plant Physiology, 137, 983-997. https://doi.org/10.1104/pp.104.055087

[14] Carlquist, S. (1992) Pit Membrane Remnants in Perforation Plates of Primitive Di- 
cotyledons and Their Significance. American Journal of Botany, 79, 660-672. https://doi.org/10.2307/2444882

[15] Carlquist, S. and Schneider, E.L. (2002) Vessels of Illicium (Illciaceae): Range of Pit Membrane Remnant Presence in Perforation and Other Vessel Details. International Journal of Plant Sciences, 163, 755-763. https://doi.org/10.1086/342080

[16] Carlquist, S. and Schneider, E.K. (2004) Perforation Plate Pit Membrane Remnants and Other Vessel Details of Clethraceae: Primitive Features in Wood of Ericales. International Journal of Plant Sciences, 165, 369-375. https://doi.org/10.1086/382809

[17] Nakashima, J., Takabe, K., Fujita, M. and Fukuda, H. (2000) Autolysis during in Vitro Tracheary Element Differentiation: Formation and Location of the Perforation. Plant \& Cell Physiology, 41, 1267-1271. https://doi.org/10.1093/pcp/pcd055

[18] Esau, K. (1977) Anatomy of Seed Plants. 2nd Edition, John Wiley \& Sons, New York.

[19] Gu, A.G., Lu, J.M. and Wang, L.J. (1993) Evolutional Morphology of Vascular Plants. Jilin Science Technology Press, Changchun.

[20] Sperry, J.S. (2003) Evolution of Water Transport and Xylem Structure. International Journal of Plant Sciences, 164, 115-127. https://doi.org/10.1086/368398

[21] Schulte, P.J. (1999) Water Flow through a 20-Pore Perforation Plate in Vessels of Liquidambar styraciflua. Journal of Experimental Botany, 50, 1179-1187. https://doi.org/10.1093/jxb/50.336.1179

[22] Oda, A., Sakuta, C., Masuda, S., Mizoguchi, T., Kamada, H. and Satoh, S. (2003) Possible Involvement of Leaf Gibberellins in the Clock-Controlled Expression of XSP30, a Gene Encoding a Xylem Sap Lectin, in Cucumber Roots. Plant Physiology, 133, 1779-1790. https://doi.org/10.1104/pp.103.030742

[23] Li, Y.H. (1986) Botany. 2nd Edition, Higher Education Press, Beijing.

[24] Foster, A.S. and Gifford, E.M. (1974) Comparative Morphology of Vascular Plants. 2nd Edition, W. H. Freeman and Company.

[25] Bliss, M.C. (1939) The Tracheal Elements in the Ferns. American Journal of Botany, 26, 620-624. https://doi.org/10.2307/2436800

[26] Bierhost, D.W. (1958) Vessel in Equisetum. American Journal of Botany, 45, 534537. https://doi.org/10.2307/2439576

[27] White, R.A. (1961) Vessel in Root of Marsilea. Science, 133, 1073-1074. https://doi.org/10.1126/science.133.3458.1073

[28] Gu, A.G. and Liu, Y.X. (1987) On the Discovery of Vessels in Phyllitis. Acta Botanica Sinica, 29, 377-378.

[29] Carlquist, S. and Schneider, E.L. (1998) Origin and Nature of Vessels in Monocotyledons. 5. Araceae Subfamily Colocasioideae. Botanical Journal of the Linnean Society, 128, 71-86. https://doi.org/10.1111/j.1095-8339.1998.tb02107.x

[30] Carlquist, S. and Schneider, E.L. (2001) Vessels in Ferns: Structural, Ecological, and Evolutionary Significance. American Journal of Botany, 88, 1-13. https://doi.org/10.2307/2657121

[31] Schneider, E.L. and Carlquist, S. (1998) SEM Studies on Vessels in Ferns. 9. Dicranopteris (Gleicheniaceae) and Vessel Patterns in Leptosporangiate Ferns. American Journal of Botany, 85, 1028-1032. https://doi.org/10.2307/2446370

[32] Huang, W.Q. and Wang, H.Y. (2000) SEM Study on Vessels of Two Species in Athyrium. Natural Sciences Journal of Harbin Normal University(Natural Science), 16, 82-87.

[33] Shao, X.W., Zhu, X., Zhou, Y.L. and Li, Y.L. (2008) Study on Tracheary Elements in 
5 Species of Ferns. Journal of Beijing Normal University (Natural Science), 44, 615619.

[34] Stern, K.R., Jansky, S. and Bidlack, J.E. (2003) Introductory Plant Biology. 9th Edition, McGraw-Hill Companies, Inc., USA.

[35] Lack, A.J. and Evans, D.E. (2001) Instant Notes in Plant Biology. BIOS Science Publishers Ltd., Milton Park, England.

[36] Johansen, D. (1940) Plant Microtechnique. Clarendon Press, Oxford.

[37] Schneider, E.L. and Carlquist, S. (1998) Origin and Nature of Vessels in Monocotyledons. 4. Araceae Subfamily Philodendroideae. The Journal of the Torrey Botanical Society, 125, 253-260. https://doi.org/10.2307/2997239

[38] Li, H.F. and Re, Y. (2010) Effect on Pit Membrane and Its Remnant by Processing and Handling in SEM Observations. Abstracts of 9 th National Symposium on Plant Structural and Reproductive Biology, Xian, China.

[39] Yan, X.L. (2007) Systematic Position of Cercidiphyllaceae Based on Morphological Data. MS Dissertation, Shaanxi Normal University, Xi'an.

[40] Cronquist, A.C. (1982) Basic Botany. 2nd Edition, Harper \& Row Publishers, New York.

[41] Fahn, A. (1982) Plant Anatomy. 3rd Edition, Pergamon Press, Oxford

[42] Yu, H.C. (1954) The Relation with the Evolution of Second Xylem and Systematic Development of Plants. Acta Botanica Sinica, 3, 183-195.

[43] Yu, H.C. (1981) The Evolutionary Tendence of Second Xylem of Gymnosperm. Acta Phytotaxonomica Sinica, 19, 179-185.

[44] Zhou, L. and Jiang, X.M. (1994) Wood Anatomy and Ultrastructure of Gymnosperm of China. Forestry Press of China, Beijing.

[45] Wang, F.X., Liang, H.B., Chen, T.Q. and Wang, D.Y. (1996) Cycads in China. Guangdong Science and Technology Press, Guangzhou.

[46] Nieves, F.G., Carvajal, M. and Olmos, E. (2004) Graft Union Formation in Tomato Plants: Peroxidase and Catalase Involvement. Annals of Botany, 93, 53-60. https://doi.org/10.1093/aob/mch014

[47] Su, J.Y., Wang, L.Y., Liu, L. and Na, R. (2007) The Observation Report Looking for the Vessel in the Pinus and Picea. Yinshan Academic Journal, 21, 25-27.

\section{Submit or recommend next manuscript to SCIRP and we will provide best service for you:}

Accepting pre-submission inquiries through Email, Facebook, LinkedIn, Twitter, etc. A wide selection of journals (inclusive of 9 subjects, more than 200 journals)

Providing 24-hour high-quality service

User-friendly online submission system

Fair and swift peer-review system

Efficient typesetting and proofreading procedure

Display of the result of downloads and visits, as well as the number of cited articles

Maximum dissemination of your research work

Submit your manuscript at: http://papersubmission.scirp.org/

Or contact ajps@scirp.org 